\title{
Tuvalu Fongafale 島西岸における砂養浜計画の検討
}

\author{
Gravel Nourishment on West Coast on Fongafale Island in Tuvalu
}

\author{
宇多高明 ${ }^{1} \cdot$ 大中 晋 $^{2} \cdot$ 芹沢真澄 $^{3} \cdot{\text { 泉 } \text { 正寿 }^{4} \cdot \text { 三波俊郎 }}^{5} \cdot$ 宮原志帆 $^{5}$ \\ Takaaki UDA, Susumu ONAKA, Masumi SERIZAWA, Masatoshi IZUMI \\ Toshiro SAN-NAMI and Shiho MIYAHARA
}

\begin{abstract}
A plan of beach nourishment using coral sand and gravel on the lagoon side of Fongafale Island in Tuvalu was investigated. Field observation was carried out on June 5, 2012 and the formation of the composite slope of an offshore gentle slope covered with sand and a steep foreshore slope covered with gravel was confirmed. On the basis of this fundamental information, a method of gravel nourishment together with use of sand was investigated using the BG model. When two groins with $40 \mathrm{~m}$ length and an interval of $185 \mathrm{~m}$ were constructed along with beach nourishment, it was possible to recover the stable beach.
\end{abstract}

\section{1. まえがき}

Tuvaluは, 地球温暖化に伴う海面上昇により水没の危 機にあるとされている。しかし実際には, 首都のある Fongafale 島への人口集中（2012年で約 5000 人）により 海岸線近傍まで土地利用が進んだことから波浪災害を受 け易くなり，同時に，住民と飼育されている約 5000 頭の 豚のし尿処理がなされていなことから水質が悪化してサ ンゴ礁の健全な機能が失われるなど, 人為的インパクト への対処こそが課題となっている. とくに首都のある Fongafale島では利用可能な土地が狭く, ラグーン側の海 岸線近傍まで住宅地が迫ったため高潮位時における侵食 や越波が見過ごすことができなくなった。これらへの対 処法の検討にあたって問題となるのは, 国土がサンゴ礁 からなるため建設資材の調達が困難なことであった。一 方，1972年10月にTuvaluに襲来したCyclone Bebe時には， 大量のサンゴ砂が海岸へ打ち上げられたこと（Maragos et al., 1973）を考慮すれば, 高波浪時に打ち上げられた 礫材を周辺影響が起こらない範囲で利用することも考え られる.このことから本論文ではFongafale島西岸を対象 としてサンゴ礁起源の礫と砂を用いた養浜手法について 検討した。このためまず2012年 6 月 5 日には対象地域の 現地調査を行った上で, 芹沢ら（2006）のBGモデル （Bagnold概念に基づく3次元海浜変形モデル）を用いて 検討した.

\begin{tabular}{|c|c|c|}
\hline 1 正会員 & 工博 & $\begin{array}{l}\text { 一般財団法人土木研究センター常務理事 } \\
\text { なぎさ総合研究室長兼日本大学客員教授 } \\
\text { 理工学部海洋建築工学科 }\end{array}$ \\
\hline 2 & & $\begin{array}{l}\text { 日本工営 (株) コンサルタント海外事業 } \\
\text { 本部 }\end{array}$ \\
\hline $\begin{array}{l}3 \text { 正会員 } \\
4\end{array}$ & 博 (工) & $\begin{array}{l}\text { 海岸研究室 (有) } \\
\text { 双葉測量設計株式会社 } \\
\text { 海岸研究室 (有) }\end{array}$ \\
\hline
\end{tabular}

\section{Fongafale 島西岸の対象地区の地形特性}

Fongafale島はTuvaluのFunafuti Atollに位置し，南北 10 $\mathrm{km}$ にわたって細長く伸びた洲島であり, 首都もこの島に ある (図-1参照). Fongafale 島西岸のうち, 図-1に示す 矩形区域が本研究による養浜検討区域である。図-2はこ の区域の 2010 年 6 月 25 日撮影の衛星画像を示す。衛星画 像に明らかなように, 西岸では海岸線近傍まで住宅地が 迫っているが, 海岸線には2 2 所に狭い砂浜がある. 突

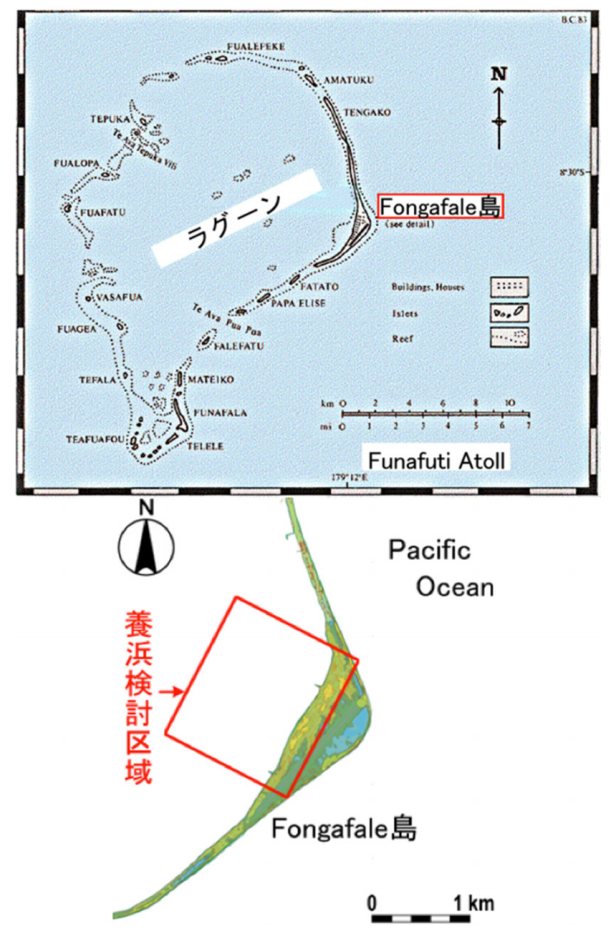

図-1 TuvaluのFongafale島の位置 


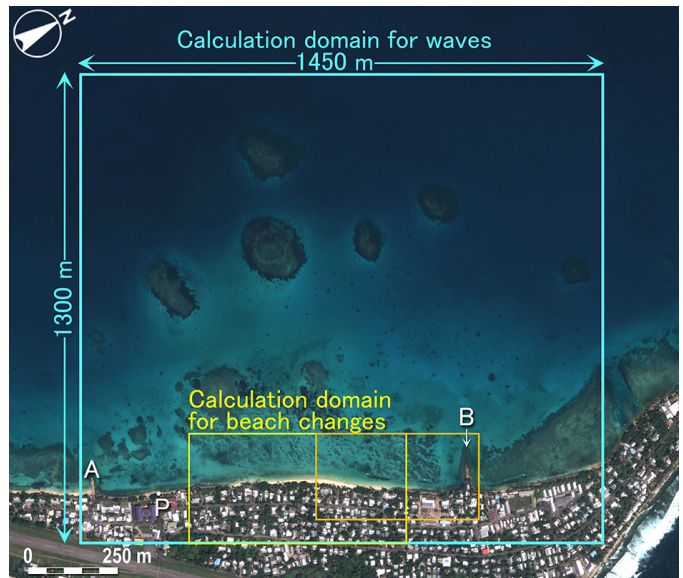

図-2 Fongafale島西岸（ラグーン側）の養浜計画地域の衛星 画像（2010年6月 25 日撮影）

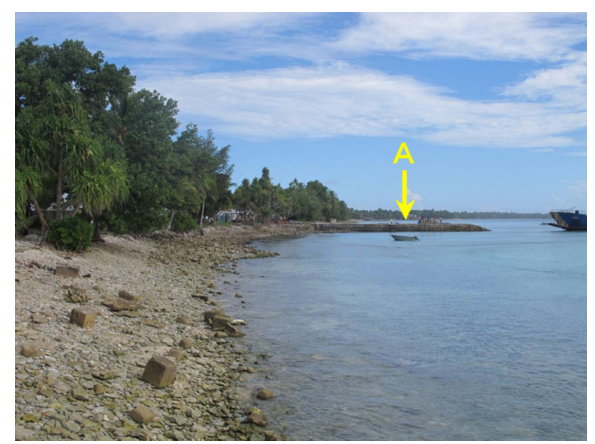

図-3 Fongafale島西岸沖のホテル前の不透過栈橋から南側の 突堤 $\mathrm{A}$ を遠望

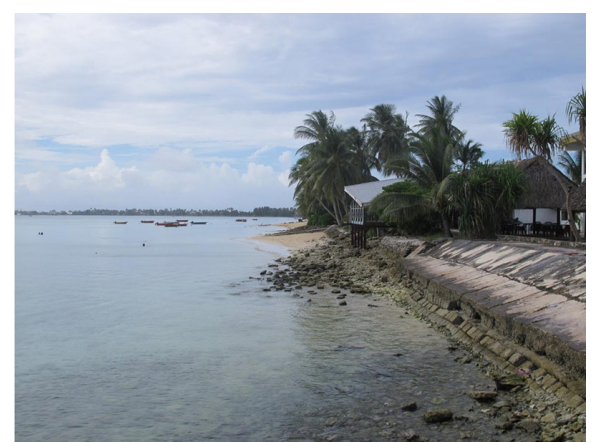

図-4 不透過栈橋の北側に隣接するViaku Lagi ホテル前の護岸

堤 $\mathrm{A}$ の南側隣接部と, 中央部の長さ約 $470 \mathrm{~m}$ の砂浜であ る. 突堤 $\mathrm{A}$ の南側から続く砂浜は突堤で切れ, その北側 には砂浜が全く存在しないことから，突堤 $\mathrm{A}$ 付近では全 体に北向きの沿岸漂砂が卓越していると見られる。いま 突堤 $\mathrm{A}$ の南側隣接部の平均汀線に対する法線を引き, そ の方向角を求めると $\mathrm{N} 300^{\circ} \mathrm{E}$ となる.

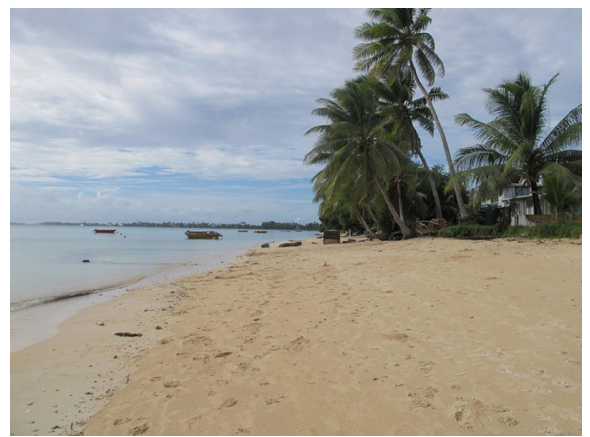

図-5 沖合の岩礁背後に形成された安定な砂浜

一方，中央部の砂浜は，沖合にある多数の岩礁背後で 発達していることから, 天然の離岸堤（岩礁）による波 の遮蔽域に形成された舌状砂州であり，現況でほぼ安定 状態にあると考えられる。舌状砂州の北側に位置する矢 印Bは，太平洋戦争中に米軍が建設したCatalina飛行艇 のRampであるが，その南側は掘削されたため局所的に 水深が大きい.

\section{3. 現地状況から学ぶ養浜の考え方}

2012年 6 月 5 日の干潮時, 養浜計画地である Fongafale 島中央部西岸の現地調査を行った。踏査は, 図-2の点 $\mathrm{P}$ より北向きに移動しつつ行った．点Pには小規模な不透 過栈橋が伸びており，そこから南側を望むと図-3のよう に長さ $46 \mathrm{~m}$ の突堤 $\mathrm{A}$ が伸びていた。この突堤は, 北向き の沿岸漂砂を阻止しているため突堤北側の汀線は凹状 で，磨耗の進んだサンゴ砂が満潮時汀線付近に集中的に 堆積していた。一方，不透過栈橋の北側直近では図-4の ように南側の突堤と不透過栈橋による沿岸漂砂阻止の影 響が重なって現われたため, 傾斜護岸の基礎が露出する まで侵食されていた。しかし，その北側では沖合の浅瀬 による遮蔽効果により形成された砂の堆積域が遠望され た. 図-5は海浜が最も広い中央部の状況を示すが，主に 中砂が堆積していた。ささにこの付近の満潮時汀線は, 図-6のように径が数 $\mathrm{cm}$ のサンゴ砂で覆われており, そ の勾配はほぼ1/3.5であり, 礫の堆積域の沖側の砂の堆 積域とはきれいな遷急線で区分されていた。しかし砂浜 は北側では次第に狭まって磕浜に変わり（図-7）。さら にその北側では図-8のようにコンクリート片が散乱した 状態となっていた。そこで図-8に示す状況を養浜により 改善できないかどうか検討することとなった。その際， 現地海岸では, 図-6のように砂と碩からなる複断面海浜 が既に形成されていることから，これを参考として設計 を行えば安定な断面形が創生可能と考えられ，また，砂 礫の沿岸方向の移動は突堤により阻止すればよいと考え られた。 


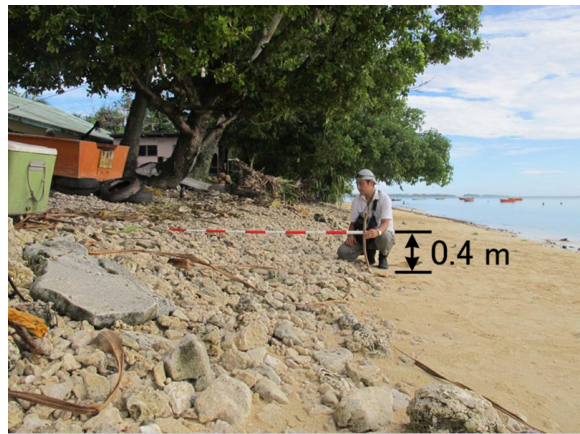

図-6 満潮時汀線付近に集積したサンゴ礫

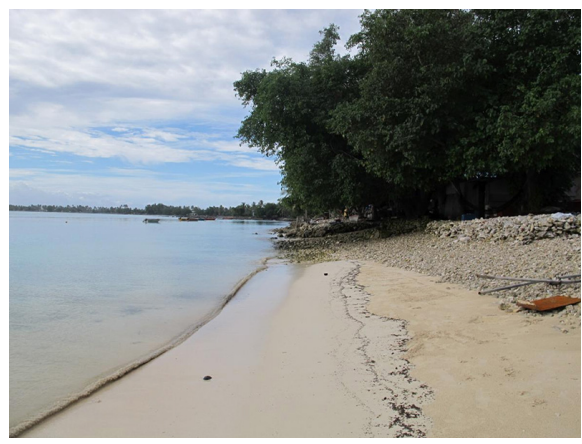

図-7 砂浜の北端部

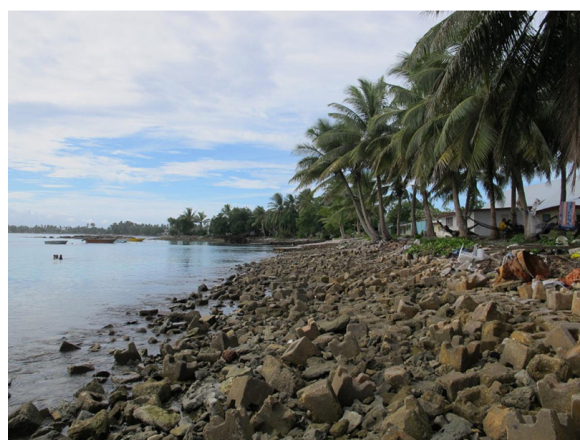

図-8 コンクリート片で覆われた養浜予定地

\section{4. 計算条件}

波浪場は，間瀬ら（1999）によるエネルギー平衡方程 式法により計算した。また，地形変化計算には，芹沢ら （2006）によるBGモデル（Bagnold概念に基づく3次元海 浜変形モデル）を用いた。計算時の潮位は, MHWS $=\mathrm{CDL}+2.8 \mathrm{~m}$ とした。なお, Tuvaluでの MSLは $\mathrm{CDL}+2.0 \mathrm{~m}$ にある。波浪条件としては, Fongafale島のラ グーン側に位置するFunafuti港における 1999〜2008年の 風観測データを基にS-M-B 法で推算した波浪データより

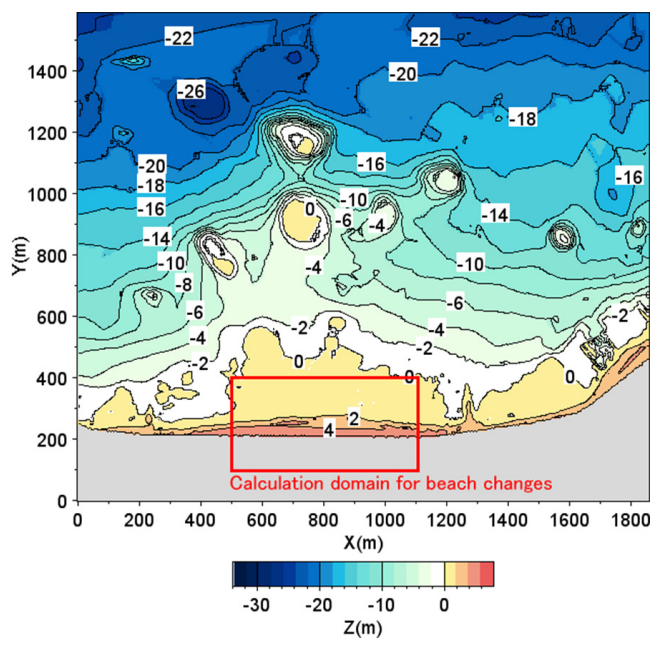

図-9 Fongafale 島西岸沖の海底地形（2010年測量）

得られたエネルギー平均波浪の波高 $H=0.52 \mathrm{~m}$, 周期 $T=3.6 \mathrm{~s}$ を用いた。地形変化計算では実測縦断形を基に, バーム高 $h_{R}$ を $1.2 \mathrm{~m}(\mathrm{CDL}+4.0 \mathrm{~m})$, 波による地形変化の限 界水深 $h_{c}$ を $1.8 \mathrm{~m}(\mathrm{CDL}+1.0 \mathrm{~m})$ とした。平衡勾配につい ては, MSL以浅に堆積している礫斜面の勾配として $1 / 3.5$ (図-6参照), MSL 以深に堆積した砂斜面の勾配として 1/10（図-5参照）とした。なお，これらの平衡勾配に対 応する底質としては径数 $\mathrm{cm}$ の礫と中砂である。また， 地形変化計算ではMLWS $(\mathrm{CDL}+1.2 \mathrm{~m})$ における水深 $2 \mathrm{~m}$ （CDL-0.8m） 以深は固定床として扱った. 境界条件とし ては計算領域の両端および沖端を横切る漂砂を 0 とした.

図-9は2010年実施の深浅測量結果を示す。基準面は $\mathrm{CDL} \pm 0 \mathrm{~m}$ に定めている. 沖合には多数の礁が分布する とともに, Catalina Rampの南側の砂浜が残されている区 域には汀線から伸びた広い浅瀬がある。深浅図の $X=1300 \mathrm{~m}$ 付近にはCatalina Rampの残骸が残されている. 再現計算における検証汀線は, 1941年撮影の空中写真か ら読み取った值を対象とするが，1941年にはCatalina Rampは存在していなかったことから，再現計算では， Catalina Rampの突出部を取り除き, 滑らかな等深線形状 として波浪場を算出し, さらに地形変化計算を行った. 一方, 養浜時の予測計算では現況のCatalina Rampの突出 部が残された状態で計算を行った。

地形変化計算では波向の設定が最も重要となる. 前述 のFunafuti港の風データによる波浪推算結果によれば, エネルギー平均波の入射波向は $\mathrm{N} 288.4^{\circ} \mathrm{E}$ と得られた。 しかしこの入射波向を与えれば実測汀線がそのまま再現 可能とは限らない. そこで本研究では, 実測值を参考と しながらも trial and errorの手法により最適波向を定めた。 このため入射波向を種々変えて波浪場を計算し, その結 


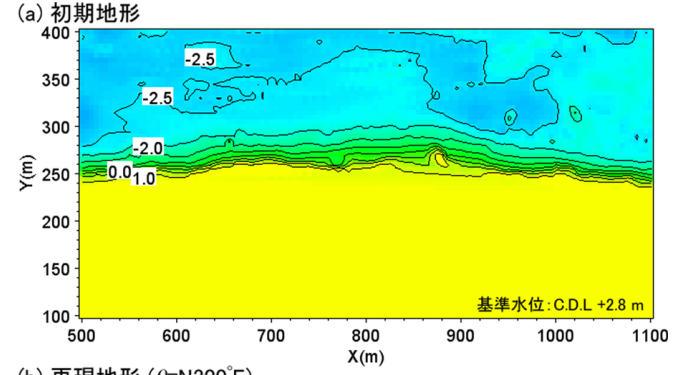

(b) 再現地形 $\left(\theta=\mathrm{N} 300^{\circ} \mathrm{E}\right)$

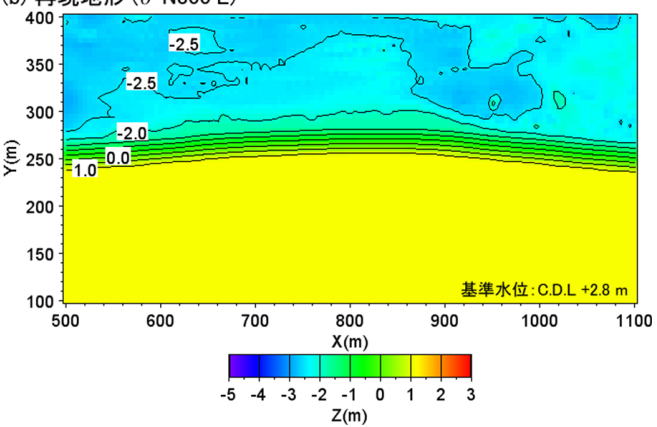

図-10 再現計算で与えた初期地形と入射波向 $\mathrm{N} 300^{\circ} \mathrm{E}$ をえ て計算した再現地形

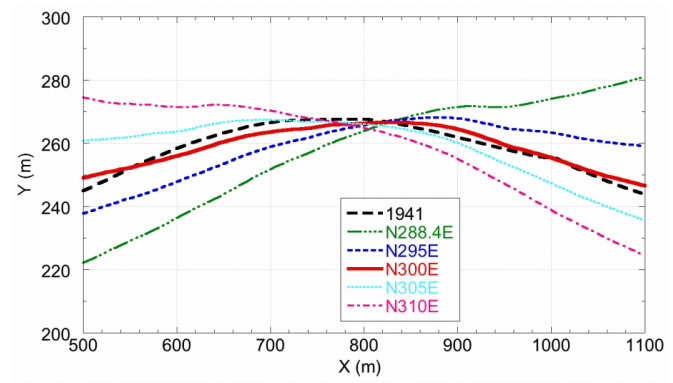

図-11 入射波向を 5 通り変えた場合の汀線形状と実測汀線形 状の比較

果を用いて汀線形状を算出した上で，1941年の汀線形状 を最もうまく再現できる波向を最適波向とした，入射波 向の設定では，実測のエネルギー平均波向 $\mathrm{N} 288.4^{\circ} \mathrm{E}$ と ともに, $\mathrm{N} 295^{\circ} \mathrm{E} \sim \mathrm{N} 310^{\circ} \mathrm{E}$ を $5^{\circ}$ ピッチで変えた波向を 設定して計算を行った.

\section{5. 再現計算の結果}

再現計算は，図-9に示す舌状砂州を囲む矩形領域を対 象とし，1941年の汀線形状を再現することによって行っ た. Catalina Rampの突出部は1941年当時には存在してい なかったことから，この突出部を取り除いて滑らかな等 深線形状として波浪場の計算㧍よび地形変化計算を行っ た。図-10（a）は再現計算用の初期地形を示す。この初期 地形に 5 方向から波を入射させて地形変化の計算を行っ

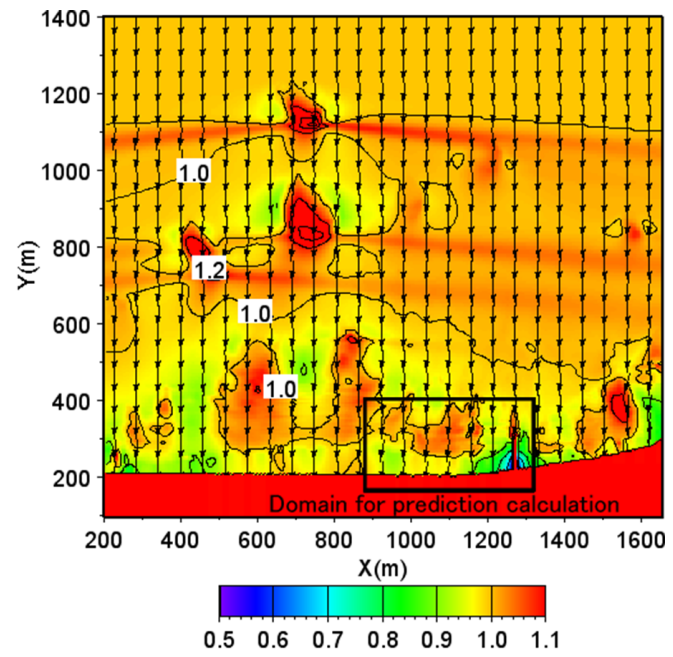

図-12 入射波向 $\mathrm{N} 300^{\circ} \mathrm{E}$ を党た場合の屈折係数と波向分布

た．例えば，図-10（b）は入射波向を $\mathrm{N} 300^{\circ} \mathrm{E}$ とて 5 年 間波を作用させて求められた再現計算結果を示す。汀線 付近が急勾配で，その沖が緩やかな勾配の海底面となる という計算結果が得られた。図-11 は, 入射波向を 5 通り 変化させた場合の汀線形状と，1941年の実測汀線との比 較結果を示す。これによれば，実測汀線と最も適合する

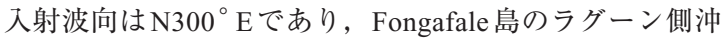
での波浪観測によるエネルギー平均波の入射波向 $\mathrm{N} 288.4^{\circ} \mathrm{E}$ よも約 $12^{\circ}$ 北寄りに傾いた角度であった。こ のことから以下の予測計算での入射波向は $\mathrm{N} 300^{\circ} \mathrm{E}$ とし た。な押，この波向は図-2 に示した突堤 $\mathrm{A}$ の南側隣接部 の平均汀線に対する法線の方向角 $\mathrm{N} 300^{\circ} \mathrm{E}$ と一致した。

\section{6. 養浜時の海浜変形計算}

養浜時海浜変形計算では，現況のCatalina Rampがある 地形条件下で，再現計算により得られた最適波向 $\mathrm{N} 300^{\circ} \mathrm{E} て ゙$ 波を入射させて地形変化計算を行った，互い に $185 \mathrm{~m}$ 離れた位置に突堤を配置して突堤間で矩形状に 養浜を行い，波を作用させて静的安定形状を求めた。突 堤は，南側にある砂浜をできるだけ保存すると同時に， 北端ではCatalina Rampの南側隣接部にある深みを避ける 位置に設置した。なお，過去の空中比較によれば，再現 計算を行った図-9に示す砂浜は安定的に存在しており, ほとんど汀線変動も生じていないことから，対象区域の 汀線にほぼ直角方向から入射すると考えられる。また， 養浜区域の両端に設置する突堤は沿岸漂砂を阻止するこ とのみを目的とするために長さは最小限でよく，また直 線状のため波の遮蔽効果はほぼ無視できる。よって計算 においては，遮蔽効果を無視した。

図-12 は最適波向 $\mathrm{N} 300^{\circ} \mathrm{E}$ をえた場合の屈折係数と波 

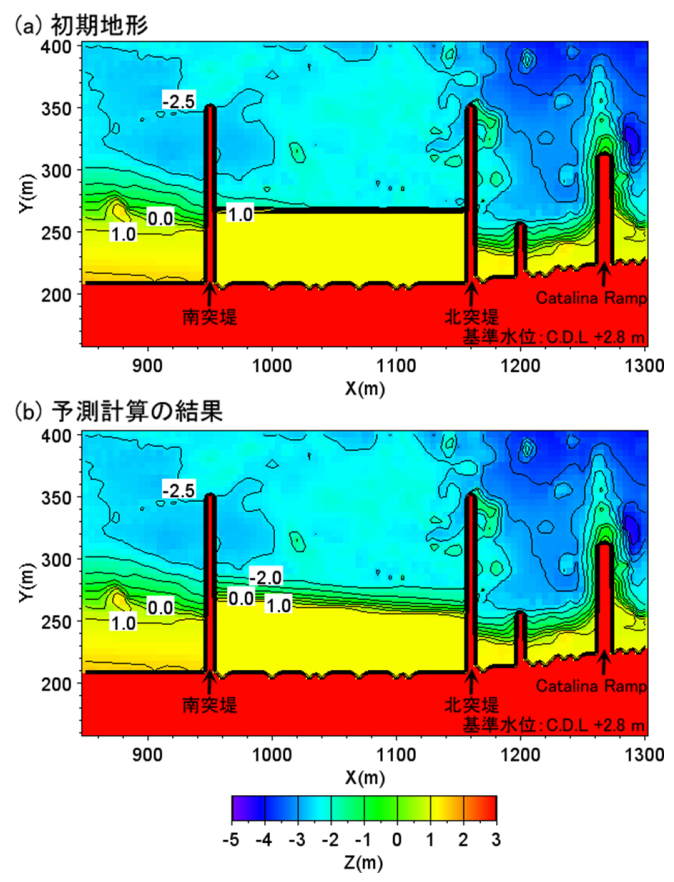

図-13 養浜後の海浜形状予測

（a）初期および予測汀線形状

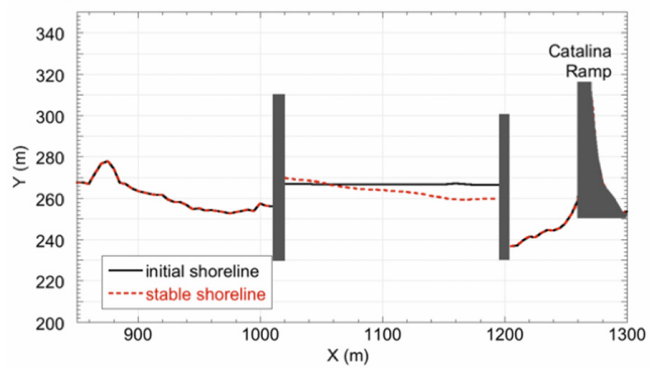

(b) 安定海浜地形にさらに 5 年間波を作用させた場合の汀線形状

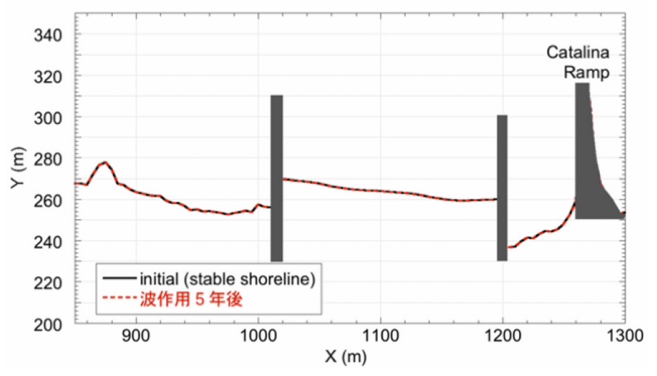

図-14 汀線形状の比較

向の分布を示す．波は汀線とほぼ直角方向から入射する が，沖合の岩礁（浅瀬）では局所的に波高が高まり，そ の周辺では波高が低下している。この波浪場を与えて図13 (a) のように現況海岸線とほぼ平行に幅 $60 \mathrm{~m}$, 初期海 浜高を $1.2 \mathrm{~m}$, 初期勾配を $1 / 2$ の盛土養浜として地形変化

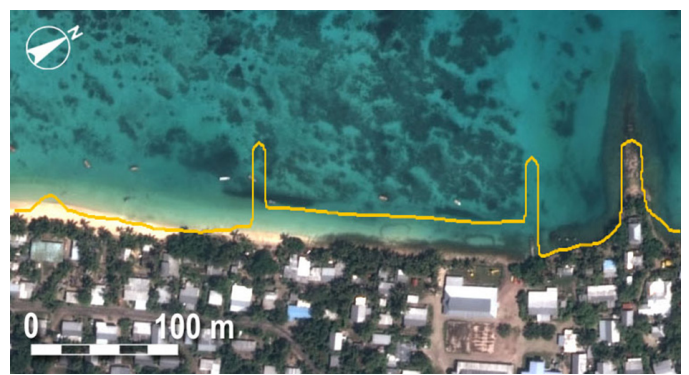

図-15 衛星画像上に落とした予測汀線

計算を行った結果を図-13（b）に示す，図-12の波浪場に 示されるように，養浜区域の沖合の $1.0 \mathrm{~m}$ の等深線が斜め に走り, 北側で水深が大きいため, 汀線付近に到達する 波はやや右回りの方向となる.このため現況の海岸線と 平行に養浜された汀線は, 右回りに約 $3^{\circ}$ 回転し, 5 年後 には安定形状に達した。図-14は汀線形状の比較を示す. 図-14 (a) は初期および予測汀線形状の比較, 図-14 (b) は図-13(b) に示す安定地形に対して波をさらに 5 年間作 用させた場合の汀線変化を示す．波を作用させても汀線 は変化しないことから汀線の安定性が確認できる，最後 に図-15には2010年6月25日撮影の衛星画像上に予測汀 線を重悋書きした結果を示す. 予測汀線は現況を養浜量 に応じて沖向きに平行移動した結果となった。

\section{7. まとめ}

Fongafale島西岸を対象としてサンゴ礁起源の磁と砂 を用いた養浜手法について検討した．まず，2012年6月 5 日に実施した現地調查によれば, 現地海岸での海浜の 発達状況として, 緩勾配の砂浜の陸側端に急勾配をな して砂が堆積し, この姿で安定している事実が確認さ れた，そこでこれをヒントとして芹沢ら（2006）のBG モデルを用いて礫養浜について検討した。この結果, 相互に $185 \mathrm{~m}$ 離れた場所に長さ約 $40 \mathrm{~m}$ の突堤を伸ばした 上で養浜を行えば, 現況で侵食された海浜を侵食以前 の姿に復元可能なことが分かった。この手法では現地 で入手可能な土砂を用いることから，その実現性が高 いと考えられる.

\section{参 考 文 献}

芹沢真澄・宇多高明 -三波俊郎 - 古池 鋼 (2006)：Bagnold 概念に基づく海浜変形モデル，土木学会論文集 B, Vol.62, No.4, pp.330-347.

間瀬 肇・高山知司・国富将嗣・三島豊秋（1999）波の回折 を考慮した多方向不规則波の変形計算モデルに関する研 究, 土木学会論文集, 628/ II 48, pp.177-187.

Maragos, J. E., Baines, G. B. K. and Beveridge, P. J. (1973): Tropical cyclone Bebe creates a new land formation on Funafuti Atoll, Science, Vol. 181, pp. 1161-1164. 